
$\$$ Research Square
Preprints are preliminary reports that have not undergone peer review.
They should not be considered conclusive, used to inform clinical practice,
or referenced by the media as validated information.

\title{
Early versus late initiation of renal replacement therapy impacts mortality in septic patients with acute kidney injury: a meta-analysis
}

\author{
Chenglong Ge \\ Xiangya Hospital Central South University \\ Yuan Jiang \\ Xiangya Hospital Central South University \\ Qianyi Peng \\ Xiangya Hospital Central South University \\ Yuhang Ai ( $\nabla$ ayhicu1978@csu.edu.cn ) \\ Xiangya Hospital Central South University
}

\section{Research}

Keywords: Acute kidney injury, Septic, Renal replacement therapy, Early, Mortality

Posted Date: March 4th, 2020

DOl: https://doi.org/10.21203/rs.3.rs-16023/v1

License: () (1) This work is licensed under a Creative Commons Attribution 4.0 International License. Read Full License 


\section{Abstract}

Background: Acute kidney injury (AKI) is a frequent complication in septic patients and increases in-hospital mortality. Our aim was to evaluate the impact of early versus late initiation of renal replacement therapy (RRT) on clinical outcomes in septic patients with acute kidney injury (AKI).

Methods: Systematic review and meta-analysis were used in this study. We searched PubMed, EMBASE, MEDLINE and Cochrane Library.

Results: Nine studies (two randomized controlled trials (RCTs) and seven retrospective cohorts) including 1694 patients were identified for detailed evaluation. This meta-analysis suggested that early RRT initiation within 48 hours (OR 0.30; $95 \%$ Cl 0.20 to 0.45 ; I 2 0\%) in septic patients with AKI reduced 28 -day mortality (odds ratio (OR) $0.56 ; 95 \%$ confidence interval (CI) 0.37 to $0.86 ; 1273 \%$ ), but intensive care unit (ICU) length of stay (LOS) (mean difference (MD) $-1.49 ; 95 \% \mathrm{Cl}-3.65$ to -0.67 ; I 2 53\%), hospital LOS (MD -3.18; 95\% Cl -7.35 to 0.99; I $241 \%$ ), the duration of RRT (MD $-2.05 ; 95 \% \mathrm{Cl}-6.86$ to 2.76 ; I $283 \%$ ) and the duration of ventilation (MD $1.99 ; 95 \% \mathrm{Cl}-2.76$ to $6.75 ; \mathrm{I} 285 \%$ ) were not influenced by the timing of RRT initiation.

Conclusions: Early initiation of RRT within 48 hours in septic patients with AKI may have a beneficial impact on survival. However, this conclusion is based on heterogeneous trials of different quality and only two RCTs. Conclusive therapeutic recommendations regarding the optimal time to initiate RRT remain uncertain.

\section{Background}

Sepsis remains extremely fatal and septic shock has a mortality rate as high as $20-60 \%$ worldwide [1-6]. Acute kidney injury (AKI) is a frequent complication in septic patients and is closely related to high mortality. Acute kidney injury associated with sepsis has a distinct pathophysiology [7], and septic patients with AKI may have a different response to renal replacement therapy (RRT) than those patients without sepsis [8, 9]. RRT is known to improve the survival rate of patients with AKI in ICU, because it rectifies metabolic acidosis by removing lactate, regulating unmeasured anions and adjusting levels of phosphate and chloride $[10,11]$. It is widely consentient that if there are life-threatening complications for septic patients with AKI, such as hyperkalemia, metabolic acidosis and acute pulmonary edema, RRT should be started immediately [5, 12-15].

However, considering the potential complications associated with RRT, the optimal timing of initiating RRT in septic patients with AKI remains controversial. Indirect evidence has indicated that early RRT could raise survival rate $[16,17]$. Recently, some randomized controlled trials (RCTs) and cohort studies reported conflicting results [18-21]. Few meta-analyses relevant to this theme has been published in the past few years. Accordingly, we conducted a systematic review and meta-analysis to investigate whether "early" versus "late" initiation of RRT in septic patients with AKI is associated with a survival benefit.

\section{Methods}

This meta-analysis was conducted and reported according to PRISMA guidelines [22].

\section{Search Strategy}

We performed a comprehensive search of PubMed, EMBASE, MEDLINE, Cochrane Library for articles from 1985 to January 2020 . The predefined key search terms included "sepsis" or "septic", and "early" or "late" or "time", and "renal replacement therapy" or "hemodialysis", and "acute kidney injury" or "acute kidney failure" or "acute renal injury". We also consulted relevant research literature at the same time.

\section{Study Criteria}

The inclusion criteria for studies included: (1) original research that related to timing of initiation of RRT in adult patients with septic AKI, (2) articles that provided exact data on mortality in septic AKI and (3) articles that reported a clear comparison of early versus late RRT initiation with a direct effect on mortality. The exclusion criteria included: (1) articles that did not report 28-day mortality, (2) studies such as comments, systemic reviews, case reports, metaanalyses, animal experimental studies etc. and (3) studies of patients who accepted RRT or with pre-existing renal disease before undergoing sepsis.

\section{Data Extraction}

Early and late RRT were defined by different criteria in original studies. The nine articles were divided into three groups according to early RRT initiation within 12 hours, within 48 hours, and unclassified. The modality of RRT was continuous renal replacement therapy (CRRT). The primary outcome was the 28-day mortality. The secondary outcomes included ICU length of stay (LOS), hospital LOS, RRT-free days and Ventilator-free days.

Data were extracted independently and the full texts of review were independently screened by two reviewers (CG and YJ) according to study criteria. The details of the selection process are shown in Fig. 1. Discrepancies were resolved between reviewers through discussion and consensus. Data extraction included the first author's name, year of publication, study design, RRT modality, definition of early and late RRT, number of patients, number of deaths, ICU LOS, hospital LOS, RRT-free days and Ventilator-free days: details are presented in Table 1 and Table 2. 
Table 1

The characteristics of studies included in the meta-analysis.

\begin{tabular}{|c|c|c|c|c|c|c|c|c|c|c|}
\hline \multirow[t]{2}{*}{ Study } & \multirow[t]{2}{*}{ Year } & \multirow{2}{*}{$\begin{array}{l}\text { Study } \\
\text { design }\end{array}$} & \multirow{2}{*}{$\begin{array}{l}\text { RRT } \\
\text { modality }\end{array}$} & \multicolumn{2}{|c|}{ Definition of early and late RRT } & \multicolumn{2}{|c|}{ Mortality at 28 days (\%) } & \multirow[t]{2}{*}{ Total } & \multirow{2}{*}{$\begin{array}{l}\text { OR } \\
(95 \% \mathrm{Cl})\end{array}$} & \multirow{2}{*}{$\begin{array}{l}\text { Quality } \\
\text { score }\end{array}$} \\
\hline & & & & Early RRT & Late RRT & Early RRT & Late RRT & & & \\
\hline $\begin{array}{l}\text { Barba } \\
{[20]}\end{array}$ & 2018 & RCT & CRRT & $\begin{array}{l}\text { within } 12 \mathrm{~h} \text { after } \\
\text { documentation } \\
\text { of failure-stage } \\
\text { AKI (RIFLE) }\end{array}$ & $\begin{array}{l}\text { after } 48 \mathrm{~h} \text { if } \\
\text { renal recovery } \\
\text { had not } \\
\text { occurred }\end{array}$ & $111 / 246(45.1 \%)$ & $102 / 242(42.1 \%)$ & 488 & $\begin{array}{l}1.13 \\
(0.79,1.61)\end{array}$ & $\mathrm{H}$ \\
\hline $\begin{array}{l}\text { Gaudry } \\
\text { [24] }\end{array}$ & 2016 & $\mathrm{RCT}$ & CRRT & $\begin{array}{l}\text { Within } 6 \mathrm{~h} \text { after } \\
\text { documentation } \\
\text { of stage } 3 \mathrm{AKI} \\
\text { (KDIGO) ** }\end{array}$ & $\begin{array}{l}\text { oliguria or } \\
\text { anuria lasted } \\
\text { for more than } \\
72 \mathrm{~h}\end{array}$ & $81 / 174(46.6 \%)$ & $78 / 174(44.8 \%)$ & 348 & $\begin{array}{l}1.07 \\
(0.70,1.63)\end{array}$ & $\mathrm{H}$ \\
\hline $\begin{array}{l}\text { Xing } \\
{[25]}\end{array}$ & 2019 & $\begin{array}{l}\text { Retrospective } \\
\text { cohort }\end{array}$ & CRRT & $\begin{array}{l}\text { within } 12 \mathrm{~h} \text { after } \\
\text { they met the } \\
\text { diagnostic } \\
\text { criteria of } \mathrm{AKI}\end{array}$ & $\begin{array}{l}\text { after } 48 \mathrm{~h} \text { if } \\
\text { renal recovery } \\
\text { had not } \\
\text { occurred }\end{array}$ & $9 / 57(15.8 \%)$ & $22 / 84(26.2 \%)$ & 141 & $\begin{array}{l}0.53 \\
(0.22,1.25)\end{array}$ & 7 \\
\hline $\begin{array}{l}\text { Yoon } \\
\text { [26] }\end{array}$ & 2019 & $\begin{array}{l}\text { Retrospective } \\
\text { cohort }\end{array}$ & CRRT & $\begin{array}{l}\text { within } 16.5 \\
\text { hours after AKI }\end{array}$ & $\begin{array}{l}\text { beyond } 16.5 \\
\text { hours after } \\
\text { AKI }\end{array}$ & $38 / 93(40.7 \%)$ & $46 / 65(70.8 \%)$ & 158 & $\begin{array}{l}0.29 \\
(0.15,0.56)\end{array}$ & 6 \\
\hline $\begin{array}{l}\text { Oh } \\
{[27]}\end{array}$ & 2016 & $\begin{array}{l}\text { Retrospective } \\
\text { cohort }\end{array}$ & CRRT & $\begin{array}{l}\text { the median } \\
\text { interval } ₫ 26.4 \mathrm{~h} \\
\text { between the } \\
\text { time of EGDT } \\
\text { enrollment and } \\
\text { the time of } \\
\text { CRRT initiation }\end{array}$ & $\begin{array}{l}\text { the median } \\
\text { interval『26.4 } \mathrm{h} \\
\text { between the } \\
\text { time of EGDT } \\
\text { enrollment } \\
\text { and the time } \\
\text { of CRRT } \\
\text { initiation }\end{array}$ & $9 / 30(30 \%)$ & $17 / 30(56.7 \%)$ & 60 & $\begin{array}{l}0.33 \\
(0.11,0.95)\end{array}$ & 7 \\
\hline $\begin{array}{l}\text { Baek } \\
\text { [28] }\end{array}$ & 2017 & $\begin{array}{l}\text { Retrospective } \\
\text { cohort }\end{array}$ & CRRT & $\begin{array}{l}\text { The time } \\
\text { interval from } \\
\text { vasopressor to } \\
\text { CRRT } \leq 24 \mathrm{~h}\end{array}$ & $\begin{array}{l}\text { The time } \\
\text { interval from } \\
\text { vasopressor } \\
\text { to CRRT } ₫ 24 \mathrm{~h}\end{array}$ & $42 / 125(33.6 \%)$ & $32 / 52(61.5 \%)$ & 177 & $\begin{array}{l}0.32 \\
(0.16,0.62)\end{array}$ & 7 \\
\hline $\begin{array}{l}\text { Shum } \\
\text { [29] }\end{array}$ & 2012 & $\begin{array}{l}\text { Retrospective } \\
\text { cohort }\end{array}$ & CRRT & $\begin{array}{l}\text { RIFLE Criteria } \\
\text { (Risk)* }\end{array}$ & $\begin{array}{l}\text { RIFLE Criteria } \\
\text { (Injury or } \\
\text { Failure) * }\end{array}$ & $15 / 31(48.4 \%)$ & $43 / 89(48.3 \%)$ & 120 & $\begin{array}{l}1.0 \\
(0.44,2.27)\end{array}$ & 8 \\
\hline $\begin{array}{l}\text { Chon } \\
\text { [30] }\end{array}$ & 2012 & $\begin{array}{l}\text { Retrospective } \\
\text { cohort }\end{array}$ & CRRT & $\begin{array}{l}\text { the time of } \\
\text { inception of } \\
\text { CRRT from } \\
\text { sepsis } \leq 24 \mathrm{~h}\end{array}$ & $\begin{array}{l}\text { the time of } \\
\text { inception of } \\
\text { CRRT from } \\
\text { sepsis } ₫ 24 \mathrm{~h}\end{array}$ & $7 / 36(19.4 \%)$ & $9 / 19(47.4 \%)$ & 55 & $\begin{array}{l}0.27 \\
(0.08,0.91)\end{array}$ & 8 \\
\hline $\begin{array}{l}\text { Carl } \\
\text { [31] }\end{array}$ & 2010 & $\begin{array}{l}\text { Retrospective } \\
\text { cohort }\end{array}$ & CRRT & BUN囚100 mg/dL & $\begin{array}{l}\text { BUN } \geq \\
100 \mathrm{mg} / \mathrm{dL}\end{array}$ & $44 / 85(52.3 \%)$ & $42 / 62(68.3)$ & 147 & $\begin{array}{l}0.51 \\
(0.26,1.01)\end{array}$ & 7 \\
\hline
\end{tabular}

*RIFLE Criteria Failure: Increase in serum Creatinine by 3 times or urine output $<0.3 \mathrm{ml} / \mathrm{kg} / \mathrm{h} \times 24 \mathrm{~h}$.

RIFLE Criteria Risk: Increase in serum Creatinine by 1.5 times or urine output $<0.5 \mathrm{ml} / \mathrm{kg} / \mathrm{h} \times 6 \mathrm{~h}$.

RIFLE Criteria Injury: Increase in serum Creatinine by 2 times or urine output $<0.5 \mathrm{ml} / \mathrm{kg} / \mathrm{h} \times 12 \mathrm{~h}$.

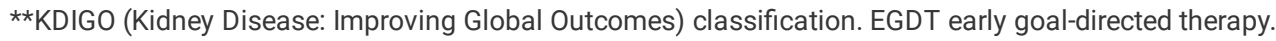

\section{Quality Assessment}

The assessment of study quality of RCTs was performed using Review Manager (version 5.3) risk-of-bias tool, including six sections: selection, performance, detection, attrition, reporting bias and other bias (Fig. 2). The Newcastle-Ottawa Scale (NOS) (range 0-9, with 9 indicating the highest quality) was used to evaluate the quality of cohort study (Table1). For cohort studies, stars are awarded after evaluation of the three main categories of selection, comparability and outcomes: a study can be awarded no more than one star for each numbered option within the selection and exposure categories and no more than two stars can be awarded for comparability [23].

\section{Statistical analysis}

Data were analyzed by Review Manager (version 5.3) and STATA statistical software (version 15.1). Estimation of effect was performed using a randomeffects model and was summarized by forest plot, with data expressed as odds ratio (OR) with $95 \% \mathrm{Cl}$ for dichotomous outcomes and mean difference (MD) with $95 \% \mathrm{Cl}$ for continuous outcomes. A random-effects model was used to deal with data because of the significant heterogeneity between studies on this topic. Heterogeneity was assessed by the Q value and I ${ }^{2}$ tests, and low, moderate, and high heterogeneity was represented by thresholds of $<25 \%, 25-75 \%$, and $>75 \%$, respectively [32]. $P \leq 0.05$ was considered statistically significant. Subgroup and sensitivity analyses were used to explore the potential sources of heterogeneity. Publication bias was assessed using a funnel plot. Meta regression analysis was used to assess the influence of baseline characteristics for possible sources of heterogeneity according to the following pre-defined variables: the year of publication, study design, definitions of early RRT. 


\section{Results}

\section{Description of included studies}

Nine studies [20, 24-31] with a total of 1694 patients ultimately met our criteria (Table 1). These references included two RCTs [20, 24] and seven retrospective cohort studies [25-31]. The characteristics and methodological quality of all trials in the meta-analysis are shown in Table 1 and the outcomes in septic patients with AKI are shown in Table 2.

Table 2

Outcomes of studies included in the meta-analysis

\begin{tabular}{|c|c|c|c|c|c|c|c|c|}
\hline \multirow{2}{*}{$\begin{array}{l}\text { Study } \\
\begin{array}{l}\text { Barba } \\
{[20]}\end{array}\end{array}$} & \multicolumn{2}{|l|}{$\begin{array}{l}\text { ICU LOS (d) } \\
\text { Early Late }\end{array}$} & \multicolumn{2}{|c|}{$\begin{array}{l}\text { Hospital LOS (d) } \\
\text { Early Late }\end{array}$} & \multicolumn{2}{|c|}{$\begin{array}{l}\text { RRT-free days } \\
\text { Early Late }\end{array}$} & \multicolumn{2}{|c|}{$\begin{array}{l}\text { Ventilator-free days } \\
\text { Early Late }\end{array}$} \\
\hline & $11(4-19)$ & $10(5-19)$ & $22(9-38)$ & $23(10-44)$ & $12(1-25)$ & $16(2-28)$ & $2(0-19)$ & $3(0-21)$ \\
\hline $\begin{array}{l}\text { Gaudry } \\
\text { [24] }\end{array}$ & $13(9-24)$ & $13(8-25)$ & $28(18-51)$ & $37(21-55)$ & $11(1-25)$ & $16(4-29)$ & $4(0-21)$ & $4(0-19)$ \\
\hline $\begin{array}{l}\text { Xing } \\
\text { [25] }\end{array}$ & $14(11-20)$ & $16(11-28)$ & $26(13-42)$ & $28(15-51)$ & NR & NR & NR & NR \\
\hline $\begin{array}{l}\text { Yoon } \\
\text { [26] }\end{array}$ & NR & NR & NR & NR & NR & NR & NR & NR \\
\hline $\begin{array}{l}\text { Oh } \\
\text { [27] }\end{array}$ & NR & $\mathrm{NR}$ & $\mathrm{NR}$ & NR & NR & $N R$ & NR & $N R$ \\
\hline $\begin{array}{l}\text { Baek } \\
\text { [28] }\end{array}$ & $13(5-32)$ & $22(8-32)$ & NR & NR & NR & NR & NR & NR \\
\hline $\begin{array}{l}\text { Shum } \\
\text { [29] }\end{array}$ & $6(3-10)$ & $7(3-15)$ & $16(6-38)$ & $16(8-37)$ & $\mathrm{NR}$ & NR & NR & NR \\
\hline $\begin{array}{l}\text { Chon } \\
\text { [30] }\end{array}$ & $12(9-27)$ & $17(9-26)$ & $41(21-69)$ & $38(17-114)$ & $14 \pm 10$ & $11.6 \pm 9.4$ & $7.5(0-20)$ & $0(0-1)$ \\
\hline $\begin{array}{l}\text { Carl } \\
\text { [31] }\end{array}$ & $27.2 \pm 39.1$ & $29 \pm 45.3$ & NR & NR & NR & NR & NR & NR \\
\hline
\end{tabular}

\section{Assessment Of Trial Quality}

Of the two included RCTs, one fulfilled all quality indicators [20], whereas the other did not perform the method of blinding for participants or describe the blinding of outcome assessment [24] (Fig. 2). The quality of seven cohort studies [25-31] were evaluated using the Newcastle-Ottawa Scale (NOS) (range 09 , with 9 indicating the highest quality) (Table 1 ).

\section{Primary Outcomes}

The OR for 28-day mortality is shown in Table 3. Early RRT initiation was associated with reduced 28-day mortality compared to late initiation (pooled OR 0.56; $95 \% \mathrm{Cl} 0.37$ to $0.86, \mathrm{P}=0.007$ ) (Fig. 3). However, there was significant statistical heterogeneity $\left(\mathrm{I}^{2}=73 \%\right)$.

Subgroup analysis was performed according to type of study (RCTs vs cohort studies; Fig. 4). In cohort studies [25-31] there was a statistically significant decrease in mortality among patients who received early RRT (OR $0.42 ; 95 \% \mathrm{Cl} 0.30$ to $0.40 ; \mathrm{I}^{2} 21 \%$ ), while mortality in the RCTs [20, 24 ] (OR $1.1 ; 95 \% \mathrm{Cl} 0.84$ to $\left.1.45 ; I^{2} 0 \%\right)$ was not statistically significant.

Besides, in another subgroup analysis based on different time of starting early RRT included seven studies [20, 24-28, 30] (Fig. 5), while two of the excluded studies were not referred to time cutoffs $[29,31]$. The incidence of mortality was significantly decreased by early initiation of RRT within 48 hours (OR 0.30 ; $95 \% \mathrm{Cl} 0.20$ to $0.45 ; \mathrm{I}^{2} 0 \%$ ) compared to initiation within 12 hours (OR $1.01 ; 95 \% \mathrm{Cl} 0.74$ to $1.38 ; \mathrm{I}^{2} 23 \%$ ).

\section{Secondary Outcomes}

Seven studies $[20,24,25,28-31]$ of the included articles described that the ICU LOS (MD - 1.49 days; $95 \%$ Cl -3.65 to $0.67 ;$ I $^{2} 53 \%$ ) (Table 3 ) was not significantly decreased in early RRT. Five $[20,24,25,29,30]$ included articles also showed that hospital LOS (MD -3.18 days; $95 \%$ Cl -7.35 to $\left.0.99 ; I^{2} 41 \%\right)$ was not significantly decreased in early RRT (Table 3). There was also no statistically significant effect on the pooled MD for RRT-free days (MD -2.05 days; $95 \%$ CI -6.86 to $2.76 ; \mathrm{I}^{2} 83 \%$ ) and Ventilator-free days (MD 1.99 days; $95 \% \mathrm{Cl}-2.76$ to $6.75 ; \mathrm{I}^{2} 85 \%$ ) (Table 3 ). 
Table 3

Meta-analysis of outcomes of early versus late RRT in patients

\begin{tabular}{|lllllll|}
\hline Outcomes & Studies & Study reference & patients & OR/MD (95\% Cl) & I $^{2}$ & p \\
\hline Primary outcomes & & & & & & \\
\hline Mortality at 28 days & 9 & {$[20,24-31]$} & 1694 & OR $0.56(0.37,0.86)$ & $73 \%$ & 0.007 \\
\hline Secondary outcomes & & & & & & \\
\hline ICU LOS & 7 & {$[20,24,25,28-31]$} & 1476 & MD -1.49 (-3.65,0.67) & $53 \%$ & 0.18 \\
\hline Hospital LOS & 5 & {$[20,24,25,29,30]$} & 1152 & MD -3.18 (-7.35,0.99) & $41 \%$ & 0.13 \\
\hline RRT-free days & 3 & {$[20,24,30]$} & 977 & MD -2.05 (-6.86,2.76) & $83 \%$ & 0.40 \\
\hline Ventilator-free days & 3 & {$[20,24,30]$} & 977 & MD $1.99(-2.76,6.75)$ & $85 \%$ & 0.41 \\
\hline
\end{tabular}

\section{Sensitivity Analysis And Publication Bias}

Sensitivity analysis indicated that the meta-analysis has low sensitivity and high stability in analysis of septic patients with AKI, which is demonstrated in Fig. 6. Funnel plots were used to assess publication bias (Fig. 7), which provided no evidence of substantial publication bias in this meta-analysis.

\section{Sources Of Heterogeneity And Meta-regression}

We performed meta-regression to explore the sources of heterogeneity. The association between early RRT initiation and 28-days mortality was not influenced by year of publication $(P=0.489)$, study design $(P=0.056)$ and time of RRT initiation $(P=0.103)$. Therefore, meta-regression analyses with these variables could not account for the large amounts of heterogeneity observed.

\section{Discussion}

This meta-analysis of 9 unique trials compared "early" versus "late" initiation of RRT in septic patients with AKI. It suggests that a strategy of early initiation of RRT is associated with improved survival. There is insufficient evidence to conclude that ICU LOS, hospital LOS, RRT-free days and Ventilator-free days are influenced by the timing of RRT initiation.

However, there were also some passive or controversial studies on the effect of early RRT in patients with AKI, such as some review articles that suggested that it was not necessary to perform early RRT for clinicians [12,33,34]. They were opposed to early RRT because it could expose patients to potential risks such as thrombosis, hemorrhage, bacteremia, hypersensitivity to the extracorporeal circuit or antibiotics, clearance of trace elements and intradialytic hypotension, which could lead to added the waste of resources [35,36]. Previous meta-analysis on this issue was not specifically focused on septic patients. Moreover, we specially excluded older studies (that is, published before 1985) because of the great advances in available technology for providing RRT and the evolution in general of interventions and technology available to support the septic patients with AKI. Accordingly, our meta-analysis is uniquely focused on how the timing of initiation of RRT impacts survival in septic patients with AKI. To explore the sources of the heterogeneity, first, we completed the subgroup analysis based on type of study and time of RRT initiation, respectively, which were statistically significant. Second, we performed sensitivity analysis, which revealed that our meta-analysis had satisfactory stability. Funnel plots indicated no publication bias in this meta-analysis. Third, metaregression included three variables (year of publication $(P=0.489)$, study design $(P=0.056)$ and time of RRT initiation $(P=0.103)$ ) that were not heterogenous. However, because the $P$ value for study design $(P=0.056)$ was close to 0.05 , we speculate that study design may be a source of heterogeneity. As for the high heterogeneity of RRT-free days and Ventilator-free days, not all the trials provided original data for the mean and standard deviation, which probably affected the heterogeneity.

Although these strengths, there are several limitations for this review. First, the number of RCTs is relatively few, so it is necessary to perform more large, multicentered RCTs to support the present results. Second, the definition of early RRT criteria was various in the included studies, which may have result in the difference in the subsequent therapeutic results in septic patients with AKI. Third, there are some limitations to retrospective studies such as the sample size, and therefore the results may not be representative of the larger public and the risk of recall bias may be higher. Finally, we found significant statistical heterogeneity. We attribute the observed heterogeneity to study design, which we were unable to account for in sensitivity analyses.

The application of RRT in septic patients with AKI is relatively common. What's more, the incidence is increasing. These patients have a risk of in-hospital mortality approaching $60 \%$ [5]. The therapeutic strategy to initiate RRT is a changeable intervention for these patients; however, it also means that the complexity and cost of their support has increased significantly. The current uncertainty about the optimal time to start RRT is a key knowledge gap, which almost certainly leads to wide variation in clinical practice. In addition, the issue is further complicated by the lack of consensus and a standard definition of the "early" RRT. At present, there are a number of clinical, biochemical and physiological factors that need to be considered when deciding to initiate RRT; However, there is still no consistent guidelines or rigid evidence to guide clinicians on this issue. In future randomized trials, a broad consensus on eligibility criteria and operational definitions for 'early' or 'standard' initiation of RRT in septic patients with AKI would be needed to ensure the feasibility of treatment options. Understanding ways to further optimize acute RRT is critical to improve patient outcomes, guide resource utilization, and provide reasonably standardized care. 


\section{Conclusions}

In summary, our meta-analysis suggests that early initiation of RRT within 48 hours in septic patients with AKI may have a benefit on survival. However, the available evidence is based on small studies with significant differences in design and quality, and only two RCTs. Due to the lack of new evidence from more high-quality, multiple-center, large sample randomized controlled trials, conclusive therapeutic recommendations regarding the optimal time to initiate RRT remain uncertain.

\section{Abbreviations}

AKI: Acute kidney injury; CRRT: Continuous renal replacement therapy; OR: Odds ratio; Cl: Confidence interval; Cr: Creatinine; h: Hours; ICU: Intensive care unit; EGDT early goal-directed therapy; KDIGO: Kidney Disease: Improving Global Outcomes; LOS: Length of stay; MD: Mean difference; NOS: Newcastle-Ottawa Scale; NR: Not reported; RCTs: Randomized controlled trials; RRT: Renal replacement therapy

\section{Declarations}

\section{Ethics approval and consent to participate}

Not applicable.

\section{Consent for publication}

Not applicable.

\section{Availability of data and materials}

The data are available for review on request.

\section{Competing interests}

The authors declare that they have no competing interests.

\section{Funding}

This work was supported by the National Natural Science Foundation of China (No.81401099).

\section{Authors'contributions}

CG performed the literature search, reviewed articles, completed the data analysis using the Review Manager (version 5.3) and STATA statistical software (version 12.0) and wrote the manuscript. YJ and QP reviewed the articles and provided secondary reviews during the manuscript preparation. YA designed the analysis and revised the manuscript. All the authors read and approved the final version of the manuscript.

\section{Competing interests}

The authors declare that they have no competing interests.

\section{Acknowledgements}

Not applicable.

\section{Authors' information}

${ }^{1}$ Department of Critical Care Medicine, Xiangya Hospital, Central South University, Changsha, 410008 , PR China; ${ }^{2}$ Department of Critical Care Medicine, Xiangya Hospital, Central South University, Changsha, 410008, PR China; ${ }^{3}$ Qianyi Peng. PhD: Department of Critical Care Medicine, Xiangya Hospital, Central South University, Changsha, 410008, PR China; ${ }^{4}$ Yuhang Ai. PhD: Department of Critical Care Medicine, Xiangya Hospital, Central South University, Changsha, 410008, PR China.

\section{References}

1. Singer M, Deutschman CS, Seymour CW, Shankar-Hari M, Annane D, Bauer M, Bellomo R, Bernard GR, Chiche JD, Coopersmith CM et al: The Third International Consensus Definitions for Sepsis and Septic Shock (Sepsis-3). Jama 2016, 315(8):801-810.

2. Quenot JP, Binquet C, Kara F, Martinet O, Ganster F, Navellou JC, Castelain V, Barraud D, Cousson J, Louis G et al: The epidemiology of septic shock in French intensive care units: the prospective multicenter cohort EPISS study. Crit Care 2013, 17(2):R65.

3. Kaukonen KM, Bailey M, Suzuki S, Pilcher D, Bellomo R: Mortality related to severe sepsis and septic shock among critically ill patients in Australia and New Zealand, 2000-2012. Jama 2014, 311(13):1308-1316.

4. Fernando SM, Rochwerg B, Seely AJE: Clinical implications of the Third International Consensus Definitions for Sepsis and Septic Shock (Sepsis-3). CMAJ : Canadian Medical Association journal 2018, 190(36):E1058-e1059. 
5. Yoon BR, Leem AY, Park MS, Kim YS, Chung KS et al: Optimal timing of initiating continuous renal replacement therapy in septic shock patients with acute kidney injury. J Scientific reports 2019, 9(1):11981.

6. Fujii T, Ganeko R, Kataoka Y, Furukawa TA, Featherstone R et al: Polymyxin B-immobilized hemoperfusion and mortality in critically ill adult patients with sepsis/septic shock: a systematic review with meta-analysis and trial sequential analysis. Intensive Care Med 2018, 44(2):167-178.

7. Dellepiane S, Marengo M, Cantaluppi V: Detrimental cross-talk between sepsis and acute kidney injury: new pathogenic mechanisms, early biomarkers and targeted therapies. Crit Care 2016, 20:61.

8. Bellomo R, Kellum JA, Ronco C, Wald R, Martensson J, Maiden M, Bagshaw SM, Glassford NJ, Lankadeva Y, Vaara ST et al: Acute kidney injury in sepsis. Intensive Care Med 2017, 43(6):816-828.

9. Levy MM, Fink MP, Marshall JC, Abraham E, Angus D, Cook D, Cohen J, Opal SM, Vincent JL, Ramsay G: 2001 SCCM/ESICM/ACCP/ATS/SIS International Sepsis Definitions Conference. Crit Care Med 2003, 31(4):1250-1256.

10. Jacobs FM, Brivet FG: Early venovenous haemodiafiltration for sepsis-related multiple organ failure. Crit Care 2006, 10(2):409; author reply 409.

11. You B, Zhang YL, Luo GX, Dang YM, Jiang B, Huang GT, Liu XZ, Yang ZC, Chen Y, Chen J et al: Early application of continuous high-volume haemofiltration can reduce sepsis and improve the prognosis of patients with severe burns. Critical Care 2018, 22.

12. Pasin L, Boraso S, Tiberio I: Early initiation of renal replacement therapy in critically ill patients: a meta-analysis of randomized clinical trials. $J$ BMC anesthesiology 2019, 19(1):62.

13. Karakala N, Tolwani AJ: Timing of Renal Replacement Therapy for Acute Kidney Injury. J Intensive Care Med 2019, 34(2):94-103.

14. Rachoin JS, Weisberg LS: Renal Replacement Therapy in the ICU. J Critical care medicine 2019, 47(5):715-721.

15. Romagnoli S, Clark WR, Ricci Z, Ronco C: Renal replacement therapy for AKI: When? How much? When to stop? Best Pract Res Clin Anaesthesiol 2017, 31(3):371-385

16. Vaara ST, Reinikainen M, Wald R, Bagshaw SM, Pettila V: Timing of RRT based on the presence of conventional indications. Clinical journal of the American Society of Nephrology : CJASN 2014, 9(9):1577-1585.

17. Gibney N, Hoste E, Burdmann EA, Bunchman T, Kher V, Viswanathan R, Mehta RL, Ronco C: Timing of initiation and discontinuation of renal replacement therapy in AKI: unanswered key questions. Clinical journal of the American Society of Nephrology : CJASN 2008, 3(3):876-880.

18. Zarbock A, Kellum JA, Schmidt C, Van Aken H, Wempe C, Pavenstadt H, Boanta A, Gerss J, Meersch M: Effect of Early vs Delayed Initiation of Renal Replacement Therapy on Mortality in Critically III Patients With Acute Kidney Injury: The ELAIN Randomized Clinical Trial. Jama 2016, 315(20):2190-2199.

19. Gaudry S, Hajage D, Schortgen F, Martin-Lefevre L, Verney C, Pons B, Boulet E, Boyer A, Chevrel G, Lerolle N et al: Timing of renal support and outcome of septic shock and acute respiratory distress syndrome: A post Hoc analysis of the AKIKI randomized clinical trial. American Journal of Respiratory and Critical Care Medicine 2018, 198(1):58-66.

20. Barbar SD, Clere-Jehl R, Bourredjem A, Hernu R, Montini F, Bruyère R, Lebert C, Bohé J, Badie J, Eraldi JP et al: Timing of renal-replacement therapy in patients with acute kidney injury and sepsis. New England Journal of Medicine 2018, 379(15):1431-1442.

21. Gaudry S, Hajage D, Schortgen F, Martin-Lefèvre L, Tubach F, Pons B, Boulet E, Boyer A, Chevrel G, Lerolle N et al: Effect of renal replacement therapy strategies in septic-shock patients with severe acute kidney injury: A post hoc analysis of a randomized controlled trial. Annals of Intensive Care 2017, 7(1):5.

22. Liberati A, Altman DG, Tetzlaff J, Mulrow C, Gotzsche PC, loannidis JP, Clarke M, Devereaux PJ, Kleijnen J, Moher D: The PRISMA statement for reporting systematic reviews and meta-analyses of studies that evaluate health care interventions: explanation and elaboration. Journal of clinical epidemiology 2009, 62(10):e1-34.

23. Stang A et al: Critical evaluation of the Newcastle-Ottawa scale for the assessment of the quality of nonrandomized studies in meta-analyses. J European journal of epidemiology 2010, 25(9):603-605.

24. Gaudry S, Hajage D, Schortgen F, Martin-Lefevre L, Pons B, Boulet E, Boyer A, Chevrel G, Lerolle N, Carpentier D et al: Initiation Strategies for RenalReplacement Therapy in the Intensive Care Unit. N Engl J Med 2016, 375(2):122-133.

25. Xing Z-Q, Liu D-W, Wang X-T, Long Y, Zhang H-M, Pan P, Su L-X: Early initiation renal replacement therapy for fluid management to reduce central venous pressure is more conducive to renal function recovery in patients with acute kidney injury. Chinese medical journal 2019, 132(11):1328-1335.

26. Yoon BR, Leem AY, Park MS, Kim YS, Chung KS: Optimal timing of initiating continuous renal replacement therapy in septic shock patients with acute kidney injury. Sci Rep 2019, 9(1):11981.

27. Oh HJ, Kim MH, Ahn JY, Ku NS, Park JT, Han SH, Choi JY, Han SH, Yoo TH, Song YG et al: Can early initiation of continuous renal replacement therapy improve patient survival with septic acute kidney injury when enrolled in early goal-directed therapy? Journal of Critical Care 2016, 35:51-56.

28. Baek SD, Yu H, Shin S, Park H-S, Kim M-S, Kim SM, Lee EK, Chang JW: Early continuous renal replacement therapy in septic acute kidney injury could be defined by its initiation within 24 hours of vasopressor infusion. Journal of critical care 2017, 39:108-114.

29. Shum HP, Chan KC, Kwan MC, Yeung AW, Cheung EW, Yan WW: Timing for initiation of continuous renal replacement therapy in patients with septic shock and acute kidney injury. Therapeutic apheresis and dialysis : official peer-reviewed journal of the International Society for Apheresis, the Japanese Society for Apheresis, the Japanese Society for Dialysis Therapy 2013, 17(3):305-310.

30. Chon GR, Chang JW, Huh JW, Lim CM, Koh Y, Park SK, Park JS, Hong SB: A comparison of the time from sepsis to inception of continuous renal replacement therapy versus RIFLE criteria in patients with septic acute kidney injury. Shock 2012, 38(1):30-36.

31. Carl DE, Grossman C, Behnke M, Sessler CN, Gehr TW: Effect of timing of dialysis on mortality in critically ill, septic patients with acute renal failure. Hemodialysis international International Symposium on Home Hemodialysis 2010, 14(1):11-17.

32. Higgins JP, Thompson SG, Deeks JJ, Altman DG: Measuring inconsistency in meta-analyses. BRITISH MEDICAL JOURNAL 2003, 327(7414):557-560.

Page $7 / 11$ 
33. Yang XM, Tu GW, Zheng JL, Shen B, Ma GG, Hao GW, Gao J, Luo Z: A comparison of early versus late initiation of renal replacement therapy for acute kidney injury in critically ill patients: an updated systematic review and meta-analysis of randomized controlled trials. BMC nephrology 2017, $18(1): 264$.

34. Li Y, Li H, Zhang D: Timing of continuous renal replacement therapy in patients with septic AKI: A systematic review and meta-analysis. Medicine (Baltimore) 2019, 98(33):e16800.

35. Gibney RT, Bagshaw SM, Kutsogiannis DJ, Johnston C: When should renal replacement therapy for acute kidney injury be initiated and discontinued? Blood purification 2008, 26(5):473-484.

36. Zou H, Hong Q, Xu G: Early versus late initiation of renal replacement therapy impacts mortality in patients with acute kidney injury post cardiac surgery: a meta-analysis. Crit Care 2017, 21(1):150.

\section{Figures}

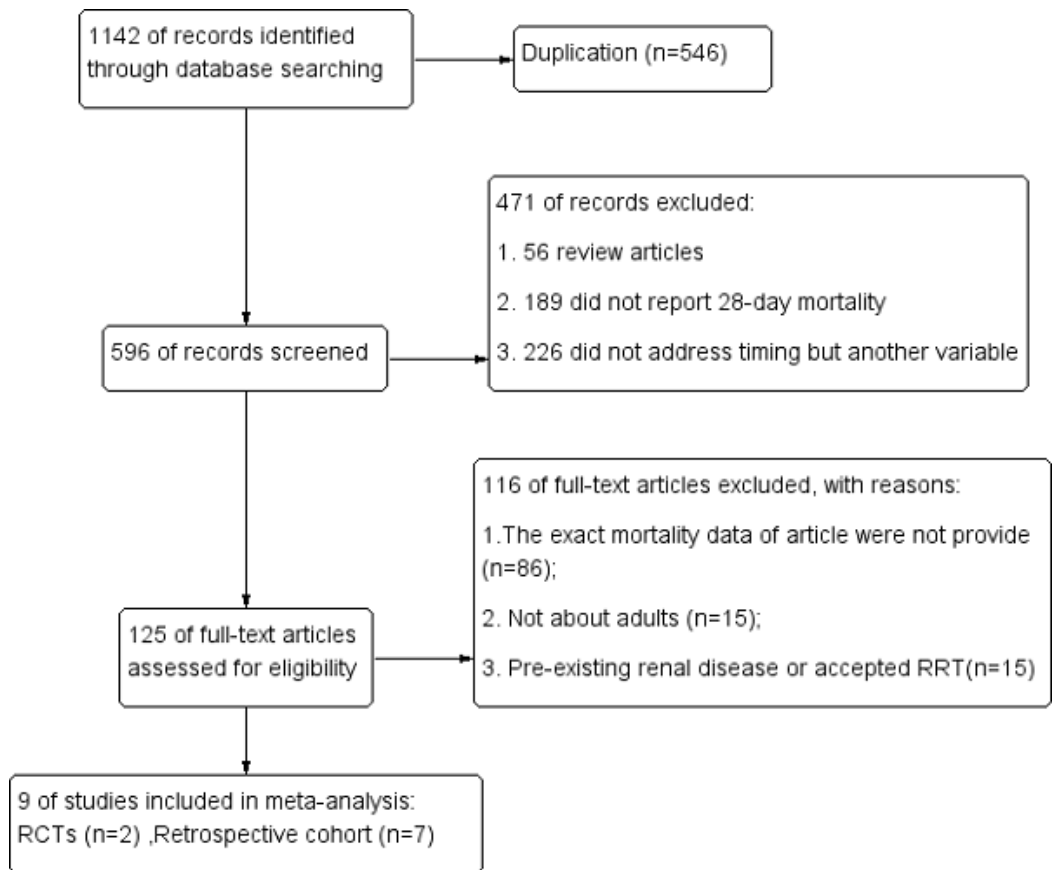

\section{Figure 1}

Study flow diagram. 


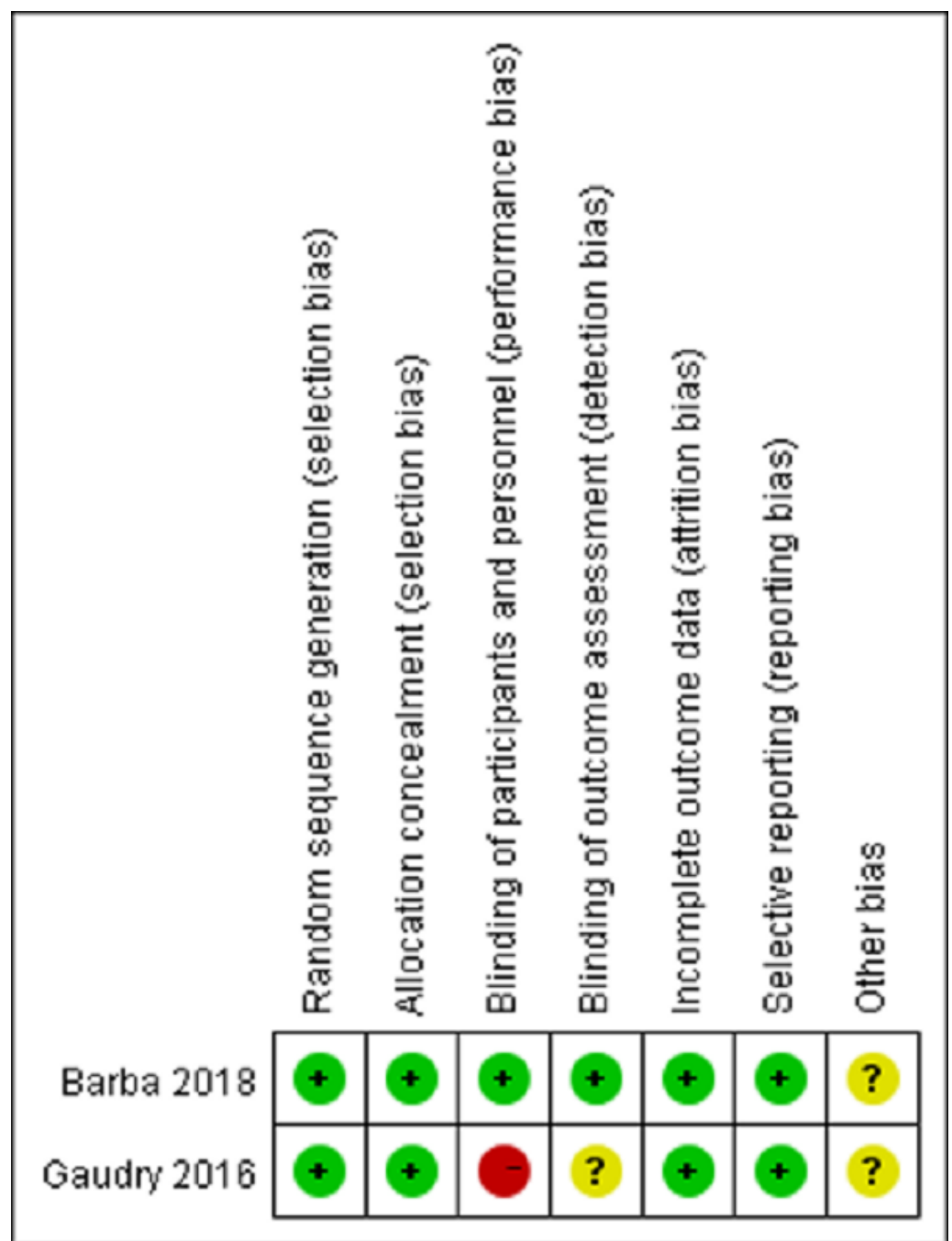

Figure 2

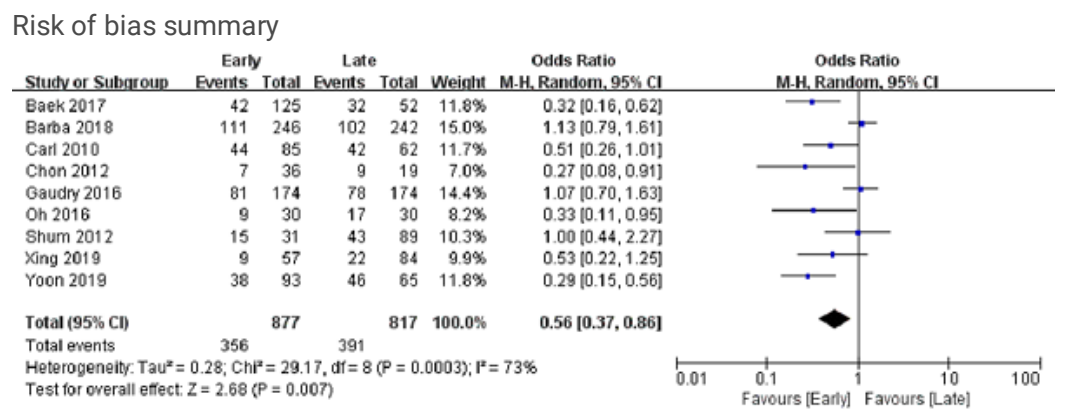

Figure 3

Forest plots of all 9 studies. 


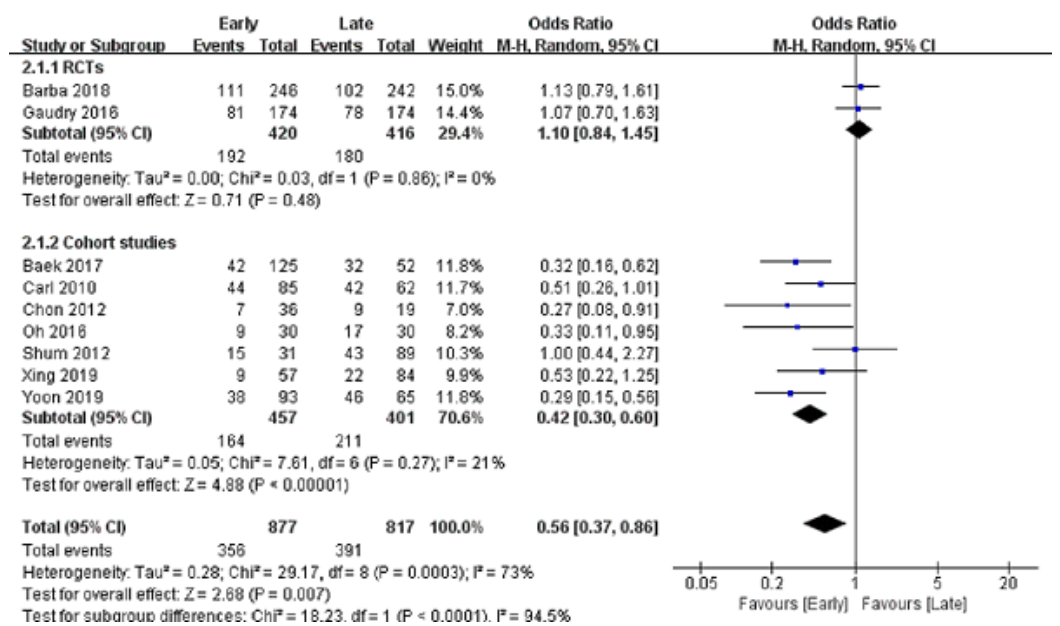

\section{Figure 4}

Subgroup analysis: the relationship between study design and mortality.

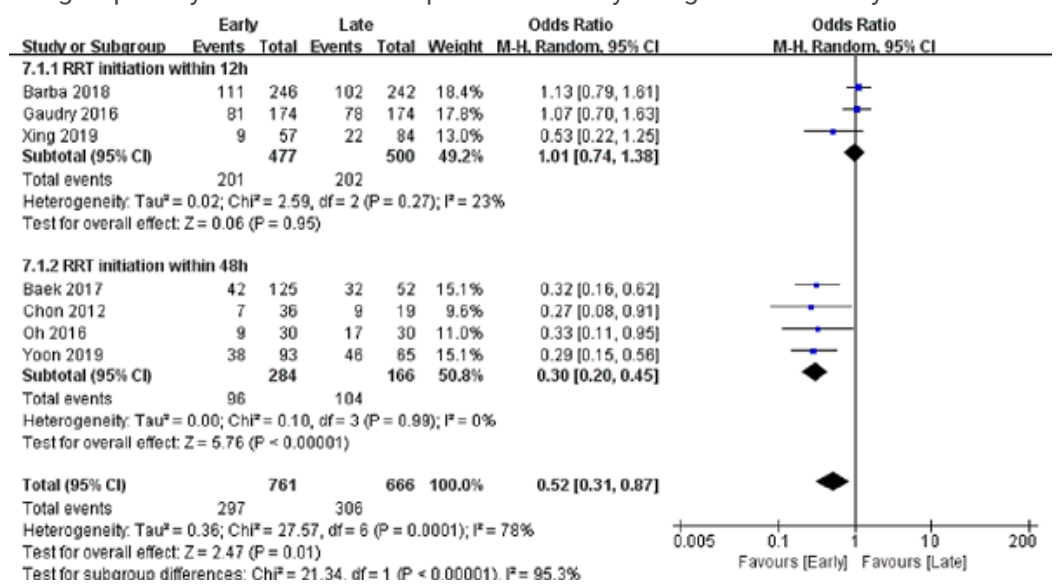

\section{Figure 5}

Subgroup analysis: the effect of the time of starting early RRT on mortality.

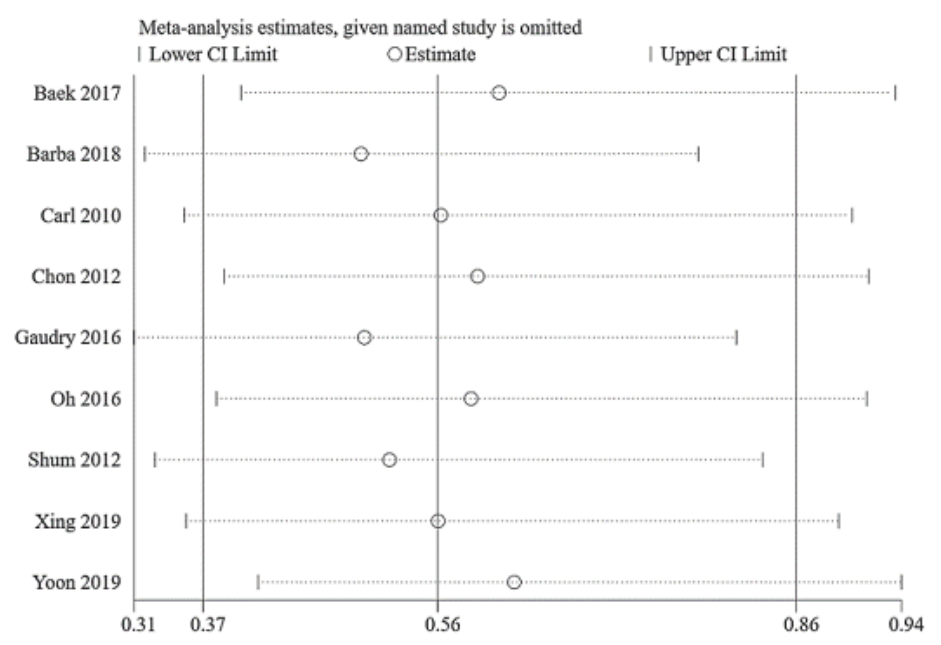

\section{Figure 6}

Sensitivity analysis shows the meta-analysis has low sensitivity and satisfactory stability. 


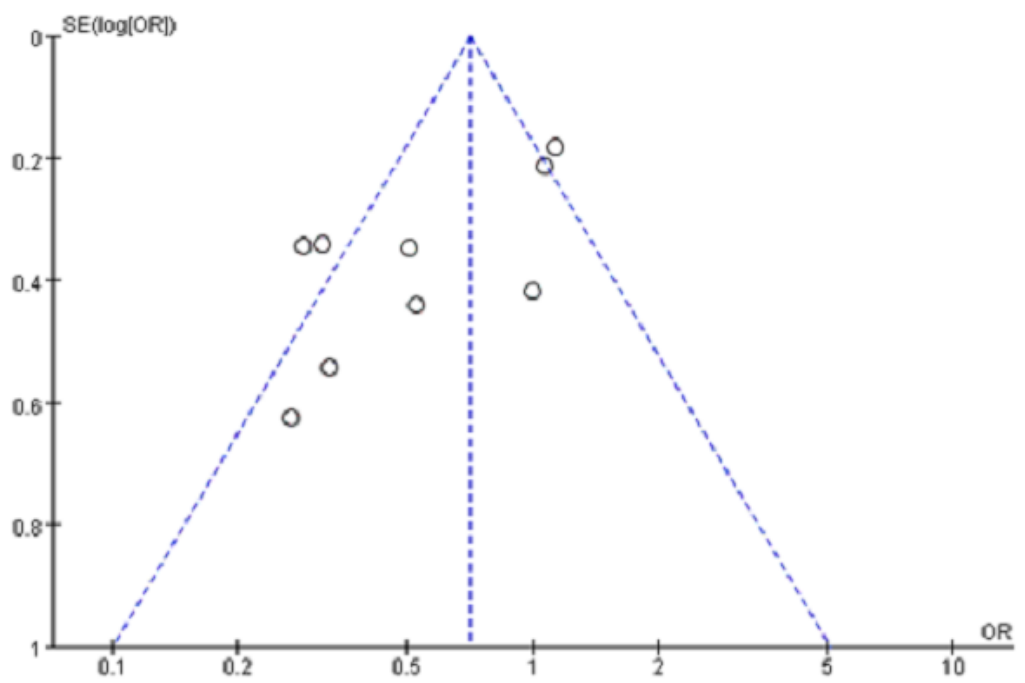

Figure 7

Funnel plot of all 9 studies. 